\title{
COMMENTARY
}

\section{THE HUMAN RIGHTS DIMENSION IN THE REVISED RSPO PRINCIPLES \& CRITERIA}

\author{
Helena Varkkey
}

\begin{abstract}
This paper focuses on the recent inclusion of Principle 6 pertaining to human rights issues into the newly revised Roundtable on Sustainable Palm Oil (RSPO) Principles and Criteria $(P \& C)$. It provides a brief overview of RSPO's track record on human rights issues prior to the inclusion of this principle, and what changes this principle will bring in the implementation of RSPO standards. It will also discuss the industry response to this new principle, which has largely been negative. The paper will offer an alternative analysis of the benefits of including this human rights principle for RSPO and for the industry as a whole.
\end{abstract}

Keywords: RSPO, palm oil, human rights, standards, industry perspective

\section{INTRODUCTION}

The Roundtable on Sustainable Palm Oil (RSPO) is arguably the most well-known global certification body for the palm oil industry. It was founded in Malaysia in 2004, and today it certifies more than 20 percent of palm oil produced globally. The Roundtable works together with various stakeholders of the industry (producers, processors or traders, consumer goods manufacturers, retailers, banks/investors, and non-governmental organizations) to develop and implement global standards for sustainable palm oil. Its 2,317 members have committed to produce, source and/or use sustainable palm oil certified by the RSPO.

The RSPO Extraordinary General Meeting in April 2013 saw the adoption of a newly revised RSPO Principles \& Criteria (P\&C). New revisions to the $\mathrm{P} \& \mathrm{C}$ include requirements for minimizing greenhouse 
gas emissions, avoiding development on peatland, and addressing issues pertaining to corruption and human rights on plantations. These revisions are part of the RSPO's continued efforts to make Certified Sustainable Palm Oil (CSPO) more attractive to European and other Western markets. The adoption of these new P\&C did not come without a fight from the oil palm growers group within the RSPO. However, with growers representing only 15.4 percent of the RSPO membership, the growers group was unable to block this revision.

\section{PRINCIPLE 6: RESPONSIBLE CONSIDERATION OF EMPLOYEES AND OF INDIVIDUALS AND COMMUNITIES AFFECTED BY GROWERS AND MILLERS}

One of the added criterion that have been receiving much scrutiny from stakeholders have been Principle 6, which aims to ensure that the RSPO-certified palm oil has not be produced through land grabs or ensuing human rights violations, including forced labor. It calls for the convening of an RSPO Working Group on Human Rights that will provide a mechanism to identify, prevent, mitigate and address human rights issues and impacts.

The oil palm industry has been implicated in many community conflicts, mostly in relation to customary land grabs. A 2008 report by Friends of the Earth and Sawit Watch documents in detail how companies use violent tactics to grab land from indigenous communities, often with the collusion of police and authorities. Ancestral lands of these communities are commonly violated because laws do not recognize or protect their indigenous customs and right to land ownership. These lands are converted into palm oil plantations, leaving the community to suffer pollution from pesticides and fertilizers, flooding, and often also a lack of clean water. It also entrenches them further into poverty as the plantations remove the forest bounty that has been the source of their income.

A consortium of concerned Non-Governmental Organizations (NGOs), lawyers and academics uncovered serious land rights violations in oil palm plantations in Malaysia and Indonesia, including Genting Plantations developing on customary lands of the Sungai and Dusun peoples in Sabah, IOI Group violating customary rights 
of Kayan and Kenyah communities in Sarawak, and Wilmar taking over the lands of the Batin Sembilan, Dayak and Minangkabau peoples in Kalimantan and Sumatra. ${ }^{1}$ Even more sinister is the alleged beheadings of up to 30 community members by security forces hired to protect disputed land in South Sumatra for development into oil palm plantations.

Human rights violations within the oil palm industry have been the subject of a 2013 investigation by Bloomberg Businessweek into the conditions of workers on palm oil plantations in Sumatra and Kalimantan that are linked to a major Malaysian palm oil company, Kuala Lumpur Kepong (KLK), which is a member of the RSPO. ${ }^{2}$ KLK's shipments to Europe and North America account for 26 percent of its revenue, with its buyers including big names like Unilever, Procter \& Gamble, and Cargill. Bloomberg Businessweek reported that the KLK's contractors had enlisted thousands of low-wage workers through fraud and human trafficking, and when these workers started work, they were subject to debt bondage, beatings, exposure to hazardous materials, and other dangerous conditions. The KLK responded to this investigation by apologizing to the workers for their treatment, but said they were unaware of the abuses because their contractor ran the plantations, as the KLK does not regulate the workers.

The report estimates that up to 3.7 million workers, including thousands of child laborers face such abuse and dangerous working conditions on plantations in Indonesia. Indonesia's National Commission on Human Rights (Komnas HAM) has also documented thousands of alleged human rights violations around plantations. There is little difference in Malaysia, where foreign labor is even more vulnerable to exploitation due to their immigration status.

This highlights that the industry's enforcement of human rights standards and management of community conflicts remain weak. Despite this, the RSPO has never suspended a member for violations of labor standards or for encroaching on community lands. In short, the human costs of the palm oil boom have been largely overlooked. The Forest Peoples Programme has deemed old RSPO standards and grievances procedures 'not fit for purpose' given the sheer number of land conflicts and human rights violations ${ }^{3}$, and there is an urgent need for reform and the institutionalizing of human rights principles in the RSPO. ${ }^{4}$ 
As part of the new P\&C, companies are required to conduct a Social Impact Assessment every two years, in consultation with spokespersons from the community and workers. A mutually agreed and documented system for dealing with grievances and complaints must also be implemented. Growers and millers must also respect human rights, adhere to minimum wage rules and provide acceptable living standards for their workers. Companies are also not allowed to be involved in forced or child labour. Workers are also free to form unions, and companies must engage with these associations.

\section{INDUSTRY RESPONSE}

Oil palm growers are disgruntled at this new criterion primarily because of the added costs involved if they were to strictly abide by the new criterion, as it becomes more challenging for these growers to secure this coveted voluntary RSPO certification. As it stands, palm oil growers have to spend an estimated additional RM10 for the production of one tonne of the RSPO-certified palm oil. ${ }^{5}$ However, there is no benchmark for the premium that companies can demand for the CSPO, as prices are decided on a negotiated basis. Hence, growers claim they are often unable to cover their production costs under the old $\mathrm{P} \& \mathrm{C}$, what more these costly new ones involving improved terms for workers and communities, and increased wages.

Aside from the additional costs bound to be incurred, these new requirements are also bound to come with added scrutiny by NGOs and other stakeholders. While earlier companies were able to brush off responsibilities towards human rights as something that has to be monitored by respective governments, now the onus is set on the companies themselves. For example, companies like the KLK, who was able to save contracts with major producers like Cargill despite the recent expose on human rights violations because there were "no active charges ... that KLK has violated labor laws or is engaged in slave or child labor"6, can no longer hide behind weak governance and will now be directly accountable to the RSPO processes.

The shifting of the responsibility from government to business is indeed significant, with the two major oil palm growers, Malaysia and Indonesia often called to question on their lax attitude towards human rights principles within their jurisdictions. For example, 
Malaysia has only signed two out of the eight treaties resulting from the Universal Declaration of Human Rights (UDHR), those pertaining to the rights of women and children. And the Indonesian government has often been accused of overlooking the basic rights of their people in favor of commercial interests. The new RSPO P\&C uses the United Nations (UN) Guiding Principles on Business and Human Rights ${ }^{7}$ as a guide, which indicate that "corporations have a responsibility to respect human rights wherever they operate, independently of states' willingness and/or their ability to fulfill their own obligations." 8 The new RSPO P\&C adds a market dimension to this, by attempting to comply with the higher levels of human rights adherence in the destination markets of the CSPO.

However, the added costs and added public scrutiny has caused waning interest among growers for the RSPO certification scheme. Growers are arguing that adhering to this new criterion will not guarantee higher sales to Western countries, given the track record of the RSPO in the past, with the RSPO certification failing to increase the sales volume of the CSPO above the current 45 percent. Growers claim that the CSPO is difficult to sell due to a lack of demand unless they already have a long-term contract with committed buyers. And some argue that these markets are not very important anyway, with European and other Western nations currently consuming only 12.5 percent of the world's palm oil.

Growers have criticized the RSPO as saying that it is no longer acting as a sustainability organization for food production, but is fast transforming into a supra-national political organization. It was noted that other oilseed growers, like rapeseed, sunflower, maize and corn, which have a larger planted acreage than oil palm and also contribute significantly to the world food chain, are not subjected to such additional criteria beyond basic environmental sustainability issues.

The Indonesian Palm Oil Association (GAPKI) has already left the RSPO in 2011 in protest of the old P\&C, and to concentrate on their own certification system, the Indonesian Sustainable Palm Oil Standard (ISPO). Of late, there has been speculation that the Malaysian Palm Oil Association (MPOA), and some of its members, are also mulling over a decision to quit the grouping, in favor of what is thought to be the more manageable Malaysian Sustainable Palm Oil Standard (MSPO) that was launched in early 2015. 


\section{CONCLUSION}

Some commentators have reduced industry reaction as a failure to 'understand the big picture', and to realize the benefits of supporting human rights and other sustainability issues publicly. While it is hard to satisfy every vested interest in the sector, the revised P\&C will only help contribute towards a strong and credible framework for developing robust governance in individual countries. The RSPO remains the most widely recognized certification scheme for palm oil worldwide (something that the ISPO and future MSPO will have to contend with), and despite complaints from certain growers, the number of growers joining the RSPO has been consistently increasing from Malaysia, Indonesia, Latin America and Africa. This indicates that market demand for the CSPO has in fact not stagnated, and it is still economically beneficial to be in full compliance of the certification scheme.

\section{NOTES}

${ }^{1}$ Marcus Colchester, Norman Jiwan and Sophie Chao, "Conflict or Consent: Oil Palm Expansion and Community Rights, ” Annual World Bank Conference on Land and Poverty. Washington, DC, World Bank, 2013.

2 Benjamin E. Skinner, "Indonesia's Palm Oil Industry Rife with HumanRights Abuses,” Bloomberg Businessweek, 22 July 2013.

3 Colchester, Jiwan and Chao, Conflict or Consent.

4 Luli Pesqueira and Pieter Glasbergen, "Playing the politics of scale: Oxfam's intervention in the Roundtable of Sustainable Palm Oil," Geoforum, 2013, Vol. 45, pp. 296-304.

5 It is difficult to gauge how much individual companies actually spend in attaining certification, as they generally do not make public such costs.

6 Skinner, "Indonesia's Palm Oil Industry."

7 The Guiding Principles state that: The responsibility of business enterprises to respect human rights refers to internationally recognized human rights - understood, at a minimum, as those expressed in the International Bill of Human Rights and the principles concerning fundamental rights set out in the International Labour Organization's Declaration on Fundamental Principles and Rights at Work"

8 Colchester, Jiwan and Chao, Conflict or Consent. 